\title{
PENICILLIN AND SULPHONAMIDES IN THE TREATMENT OF INFECTIONS IN INFANCY
}

\author{
BY
}

\author{
EDWARD C. ROSS COUPER, M.D., F.R.F.P.S., D.P.H. \\ Deputy Medical Superintendent, Walton Hospital, Liverpool
}

In a previously reported series of cases, treatment with penicillin alone gave encouraging results and it was decided to test the efficacy of combining penicillin and sulphonamide therapy. The previous cases were treated during the months of September, October and November and the series about to be described was treated during the first six months of the year. ${ }^{2}$ This is a matter of some importance in planning the experiment and in assessing the results, since the virulence of the infections to which infants are prone seems to be greatest in the early months of the year.

There are now many sulphonamide drugs from which to choose but they may be divided broadly into two groups: (a) the well-absorbed sulphonamides which may be described as anti-coccal in action, e.g. sulphathiazole and sulphadiazine, and (b) the poorly absorbed sulphonamides which may be described as anti-bacillary in action, e.g. sulphasuxidine and sulphaguanidine. Sulphathiazole has been selected as representative of the first group and sulphasuxidine of the second. Bacteriological investigations show that infections by organisms of the colon bacillus group are common in the early months of life and it is possible that the use of a drug such as sulphasuxidine, which reduces the number of $\mathbf{B}$. Coli in the intestinal tract, may be of benefit. Glucose-saline by mouth was administered both to overcome dehydration if present and to assist in the elimination of the sulphonamide in the cases so treated. Subcutaneous salines and intravenous salines were also given as required.

\section{Part I}

From the above considerations it was decided to treat three sets of cases concurrently as follows:-

(A) A group treated with penicillin alone, in order to confirm that the good results previously obtained in September, October and November were continued in January, February and March.

(B) A group treated with penicillin and sulphathiazole to test the efficacy of penicillin plus a wellabsorbed, anti-coccal sulphonamide which might reinforce the action of penicillin against penicillin and sulphonamide sensitive cocci.

(C) A group treated with penicillin and sulphasuxidine to test the efficacy of penicillin plus a poorly absorbed, anti-bacillary sulphonamide which might reduce the numbers of $B$. Coli in the intestinal tract and minimize infection or prevent terminal invasion by these organisms.

Type of case. The type of case treated was as follows: bronchopneumonia, nasopharyngitis, otitis media and premature infants who go gradually downhill, a type which is frequently found at postmortem examination to have some infection which has eluded detection in life.

Dosage. Penicillin was made up in bottles containing 25,000 units dissolved in 8 c.c. of saline, and was given in 1 c.c. doses intramuscularly at threehourly intervals, each bottle lasting twenty-four hours. Occasionally twice this amount of penicillin was used.

Sulphonamide. An initial dose of 0.5 to $0.75 \mathrm{~g}$. was given followed by $0.25 \mathrm{~g}$. three-hourly. This smaller dose was given in order to coincide with the injections of penicillin. The usual dose for a mature infant in this hospital is $0.5 \mathrm{~g}$. four-hourly.

Glossary of Abbreviations.

$$
\begin{array}{rlrl}
\mathrm{D} & =\text { Diarrhoea. } & \mathrm{W} & =\text { Weight loss. } \\
\mathrm{V} & =\text { Vomiting. } & \mathrm{T} & =\text { Pyrexia. } \\
\text { De } & =\text { Dehydration. } \quad \mathrm{N} . \mathrm{W} . & =\text { = Not weighed. } \\
\text { Cy. }=\text { Cyanosis. } & & &
\end{array}
$$

\section{Group A: Penicillin alone}

Of this group eight were considered to be severely ill, three moderately ill and one mildly ill. The eight severely ill cases died. The high incidence of prematurity in this group will be noticed. This is due to the tendency, difficult to avoid, to give penicillin alone to premature infants so that their normal feeds may be continued as far as possible. The use of sulphonamides necessitates substituting glucose saline to assist the elimination of the drugs.

Symptoms. In addition to the symptoms of the disease from which they suffered, these infants showed the following general symptoms: diarrhoea 5 , vomiting 3 , dehydration 8 , pyrexia 2 , loss of weight 9 and 3 were too ill to be weighed. In the case with pyaemia the temperature was uncontrolled. Loss of weight varied from 5 to $16 \mathrm{oz}$.

COURSE OF THE ILLNESS. Among those who died, five improved at first and then relapsed. Another was doing well when its parents insisted on removing the infant from hospital against advice and brought 
TABLE 1

GROUP A: PENICILLIN ALONE

\begin{tabular}{|c|c|c|c|c|c|c|}
\hline $\begin{array}{l}\text { Case } \\
\text { No. }\end{array}$ & Diagnosis & $\begin{array}{c}\text { Clinical } \\
\text { grade }\end{array}$ & $\begin{array}{l}\text { General } \\
\text { signs }\end{array}$ & $\begin{array}{l}\text { Penicillin } \\
\text { units }\end{array}$ & Alive & Dead \\
\hline $\begin{array}{l}1 \\
2\end{array}$ & $\begin{array}{l}\text { Prematurity, bronchopneumonia and pemphigus } \\
\text { Prematurity, bronchopneumonia }\end{array}$ & $\begin{array}{l}\text { Severe } \\
\text { Severe }\end{array}$ & $\begin{array}{l}\text { D, T, W } \\
\text { D, De, W }\end{array}$ & $\begin{array}{r}193,750 \\
21,875\end{array}$ & & $\begin{array}{l}\text { D } \\
\text { D }\end{array}$ \\
\hline 3 & $\begin{array}{l}\text { Prematurity, bronchopneumonia and nasopharyn- } \\
\text { gitis. }\end{array}$ & Severe & $\mathrm{D}, \mathrm{De}, \mathrm{W}$ & $\left.\begin{array}{l}450,000 \\
300,000\end{array}\right\}$ & & $\mathbf{D}$ \\
\hline 4 & $\begin{array}{l}\text { Prematurity, jaundice, bronchopneumonia, bilateral } \\
\text { acute otitis media. }\end{array}$ & Severe & De, NW & 365,000 & & D \\
\hline 5 & $\begin{array}{l}\text { Prematurity, jaundice, bronchitis and right acute } \\
\text { otitis media. }\end{array}$ & Severe & De, W & $\left\{\begin{array}{l}225,000 \\
100,000\end{array}\right.$ & & D \\
\hline 6 & $\begin{array}{l}\text { Prematurity, jaundice, bronchopneumonia and } \\
\text { nasopharyngitis. }\end{array}$ & Severe & De, NW & 225,000 & & D \\
\hline 7 & $\begin{array}{l}\text { Prematurity, right acute otitis media with profuse } \\
\text { otorrhoea. }\end{array}$ & Mild & $\mathrm{V}, \mathrm{W}$ & $\left\{\begin{array}{l}350,000 \\
\text { Pen. drops } \\
\text { locally }\end{array}\right.$ & A & \\
\hline 8 & $\begin{array}{l}\text { Prematurity, jaundice, sclerema, atelectasis, } \\
\text { haemorrhages into lungs, left otitis media and } \\
\text { mastoiditis. }\end{array}$ & Severe & NW & 15,615 & & $\mathbf{D}$ \\
\hline 9 & Prematurity; condition deteriorating & Moderate & De, W & 200,000 & A & \\
\hline 10 & Prematurity, jaundice, pyaemia, left otitis media & Severe & W, T, De, & $\left.\begin{array}{l}425,000 \\
125,000\end{array}\right\}$ & & $\mathbf{D}$ \\
\hline 11 & Prematurity, jaundice; condition deteriorating & Moderate & De, W & $\left.\begin{array}{l}350,000 \\
300,000\end{array}\right\}$ & A & \\
\hline 12 & Bilateral acute otitis media & Moderate & $\mathrm{D}, \mathrm{V}, \mathrm{W}$ & 75,000 & $\begin{array}{l}\mathrm{A} \\
4\end{array}$ & 8 \\
\hline
\end{tabular}

her back a few days later moribund. The infant (case No. 10) who had pyaemia did very well with the first course of penicillin and its weight rose from $3 \mathrm{lb} .12 \mathrm{oz}$. to $5 \mathrm{lb}$. when an abscess and cellulitis developed on the buttock some weeks after penicillin had been stopped. Two required subcutaneous salines and in one case the buttocks broke down. In case No. 11 improvement coincided with doses of penicillin of 50,000 units per day instead of the usual 25,000 units, but in case No. 1 the larger doses were of no avail. The otorrhoea in case No. 7 continued for fourteen days but ceased in three days with penicillin drops (1000 units per c.c.) locally, and the acute inflammation of the tympanic membranes in case No. 12 settled quickly in three days. In those who recovered, weight, lost as a result of the illness, was regained in nine to twenty-three days.

BACTERIOlogy in Life. Faeces were examined in all the cases but no pathogenic organisms were discovered. In case No. 3, a severe nasopharyngitis with much nasal discharge, the nasal swab grew Staphylococcus aureus, sensitive to penicillin and sulphonamides. A second nasal swab, thirteen days later, grew coliform organisms, resistant to penicillin but sensitive to sulphonamide, and Staphylococcus albus, sensitive to penicillin and resistant to sulphonamide. Case No. 7 had profuse otorrhoea and swab from the discharge grew coliform organisms resistant to penicillin and sulphonamide. In spite of this, response to penicillin therapy was good and discharge ceased three days after local application of penicillin drops. Pus from the buttock abscess in case No. 10 grew Staphylococcus aureus, sensitive to penicillin but resistant to sulphonamide.

Post-MORTEM Findings. Permission for post- mortem examination was obtained in the eight cases who died. In cases Nos. 1, 2, 3 and 4 the presence of bronchopneumonia was confirmed by microscopic sections of the lungs. Case No. 4 also had bilateral otitis media. Case No. 5 showed the presence of bronchitis and right otitis media, while in case No. 6 there was bronchopneumonia and haemorrhages into the skin of the buttocks which were thought to be due to the injections. The lungs in case No. 8 showed complete atelectasis of the left lower lobe with extensive haemorrhages into the fully expanded parts of the lungs and blood in the trachea. From this point of view this was not a suitable case for penicillin therapy but in addition left otitis media and mastoiditis were found. In case No. 10, the case of pyaemia, the spleen was enlarged and septic, and septic infarcts in the lungs and kidneys and left otitis media were found.

Post-MORTEM Bacteriology. Swabs were taken from the ears in cases No. 4, 5, 8 and 10, with the following results. Direct smears showed coliform organisms and Gram positive cocci in cases No. 4, 5 and 8, coliform organisms alone in case No. 10 . Cultures in case No. 4 grew coliform organisms, resistant to penicillin and sensitive to sulphonamide and Staphylococcus albus, sensitive to penicillin and resistant to sulphonamide; in case No. 5 coliform organisms, resistant to penicillin and sensitive to sulphonamide and non-haemolytic streptococci, sensitive to penicillin and resistant to sulphonamide. Culture in case No. 8 was overgrown with coliform organisms, resistant to penicillin and sensitive to sulphonamide, and a similar result was obtained in case No. 10. Swabs were taken from the lungs in cases No. 4 and 5 and results similar to those of the ear swabs were obtained. 
TABLE 2

GROUP B: PENICILLIN AND SULPHATHIAZOLE

\begin{tabular}{|c|c|c|c|c|c|c|c|}
\hline $\begin{array}{l}\text { Case } \\
\text { No. }\end{array}$ & Diagrosis & $\begin{array}{l}\text { Clinical } \\
\text { grade }\end{array}$ & $\begin{array}{l}\text { General } \\
\text { signs }\end{array}$ & $\begin{array}{l}\text { Penicillin } \\
\text { (units) }\end{array}$ & $\begin{array}{c}\text { Thiazole } \\
\text { g. }\end{array}$ & Alive & Dead \\
\hline 1 & $\begin{array}{l}\text { Bronchopneumonia, otitis media and mas- } \\
\text { toiditis. }\end{array}$ & Severe & $\mathrm{D}, \mathrm{De}, \mathrm{W}$ & 381,250 & $4 \cdot 5$ & & D \\
\hline 2 & $\begin{array}{l}\begin{array}{l}\text { Prematurity, bronchopneumonia } \\
\text { pharyngitis }\end{array} \\
\begin{array}{llllll}\text { Bilateral otitis media } & \ldots & \ldots & & & \\
\end{array}\end{array}$ & Severe & $\begin{array}{l}\text { D, V, De, } \\
\text { W, V, De, } \\
\text { T, W }\end{array}$ & $\begin{array}{r}150,000 \\
50,000 \\
100,000 \\
100,000 \\
275,000 \\
225,000 \\
175,000 \\
425,000\end{array}$ & $\begin{array}{l}5 \cdot 0 \\
2 \cdot 5 \\
4 \cdot 75 \\
6 \cdot 75 \\
6 \cdot 75 \\
4 \cdot 75 \\
=\end{array}$ & A & D \\
\hline $\begin{array}{l}4 \\
5\end{array}$ & $\begin{array}{l}\text { Pneumonia and sub-mental abscess } \\
\text { Bilateral otitis media and nasopharyngitis }\end{array}$ & $\begin{array}{l}\text { Severe } \\
\text { Moderate }\end{array}$ & $\begin{array}{l}\text { W } \\
\mathrm{D}, \mathrm{W}\end{array}$ & $\begin{array}{l}100,000 \\
275,000\end{array}$ & $\begin{array}{l}8 \cdot 75 \\
5 \cdot 25\end{array}$ & A & D \\
\hline 6 & $\begin{array}{l}\text { Prematurity, nasopharyngitis, bilateral otitis } \\
\text { media, bronchopneumonia. }\end{array}$ & Severe & De, W & 65,625 & $4 \cdot 75$ & & D \\
\hline 7 & Prematurity; condition deteriorating $\ldots$ & Moderate & $\left\{\begin{array}{l}\mathrm{D}, \mathrm{V}, \mathrm{De}, \\
\mathrm{T}, \mathrm{W}\end{array}\right.$ & $\begin{array}{l}200,000 \\
150,000\end{array}$ & $\begin{array}{l}6 \cdot 25 \\
2 \cdot 5\end{array}$ & A & \\
\hline $\begin{array}{l}8 \\
9\end{array}$ & $\begin{array}{l}\text { Bilateral otitis media } \ldots \\
\text { Prematurity; condition deteriorating }\end{array}$ & $\begin{array}{l}\text { Moderate } \\
\text { Mild }\end{array}$ & $\begin{array}{l}\mathrm{D}, \mathrm{W} \\
\mathrm{De}, \mathrm{W}\end{array}$ & $\begin{array}{l}200,000 \\
250,000\end{array}$ & $\begin{array}{l}6 \cdot 25 \\
6 \cdot 25\end{array}$ & $\begin{array}{l}\text { A } \\
\text { A }\end{array}$ & \\
\hline 10 & Bilateral otitis media $\quad$.. & Moderate & $\mathrm{D}, \mathrm{T}, \mathrm{W}$ & 100,000 & $6 \cdot 25$ & $\begin{array}{c}A \\
6\end{array}$ & 4 \\
\hline
\end{tabular}

\section{Group B: Penicillin and Sulphathiazole}

In this group five were judged to be severely ill, four moderately ill and one mildly ill. Four were premature infants and two of these died.

SYMPTOMS. General symptoms occurred as follows: diarrhoea 7 , vomiting 3 , dehydration 6 , pyrexia 3 and loss of weight 10 . Temperature, which only lasted for one day after institution of treatment, varied from $101^{\circ} \mathrm{F} .-104 \cdot 8^{\circ} \mathrm{F}$. Loss of weight varied from 4 to $16 \mathrm{oz}$.

COURSE OF THE ILLNESS. In two of the cases who died (No. 1 and 2) improvement occurred at first and the patients then relapsed. In the other two no improvement was manifest. Three cases who recovered suffered from otitis media, No. 5, 8 and 10 , and the inflammation of the tympanic membranes settled in three days, seven days and eleven days respectively. The remainder progressed satisfactorily except case No. 3 , which also suffered from otitis media. In this case relapse took place on five occasions with losses of weight varying from 5 to $16 \mathrm{oz}$. The tympanic membranes seemed to settle in periods from three to eight days on the first four occasions but in the last two no evidence of parenteral infection could be found. Sulphathiazole was given with the first four courses of penicillin but not with the last two. The response was just as favourable without the sulphathiazole. Figure 1 shows this infant's weight curve from the beginning of its illness till the date of its discharge from hospital and the response to treatment is clearly demonstrated. It may be noted that at the first relapse treatment seems to have begun before weight was lost. This appearance of the graph is due to the fact that the infant became very ill the night before, when treatment was begun, and was not weighed till the following morning. At the third relapse, left myringotomy was performed as the child was very ill and dehydrated. A small bead of pus was released. The constant response to penicillin treatment suggests that this was almost certainly a penicillin-sensitive infection. In those who recovered, weight lost as a result of the illness was regained in periods varying from four to thirteen days.

BACTERIOLOGY IN LIFE. In nine instances bacteriological examination of the faeces showed no evidence of pathogenic organisms. In one case a specimen was not obtained. Case No. 2 had severe nasopharyngitis with copious nasal discharge and on two occasions swabs were taken. In the first Staphylococcus aureus, sensitive both to penicillin and sulphonamide, was grown and in the second Staphylococcus aureus, sensitive to penicillin but resistant to sulphonamide. In case No. 3 myringotomy released a small bead of pus and an attempt was made to culture with negative result. Pus from the submental abscess in case No. 4 grew Staphylococcus aureus, sensitive to penicillin and sulphonamide.

Post-MORTem Findings. Permission for postmortem examination was obtained in three of the four fatal cases with the following results. In cases No. 1 and 6 the presence of bronchopneumonia was confirmed by microscopic section. In case No. 3 microscopic section looked more like haemorrhages into the lung and congestion. In case No. 1 left otitis media and mastoiditis were found in addition and left otitis media in case No. 6.

Post-Mortem Bacteriology. Swabs from the lungs and mastoid antra in case No. 1, when cultured, grew coliform organisms, resistant to penicillin and sensitive to sulphonamide and streptococcus faecalis, resistant to both penicillin and sulphonamide. Direct smear from the lung in case No. 2 showed Gram positive cocci and cultures grew diphtheroids, sensitive to penicillin but resistant to sulphonamide. Culture from the middle ear in case No. 6 grew coliform organisms, resistant to 
TABLE 3

GROUP C: PENICILLIN AND SULPHASUXIDINE

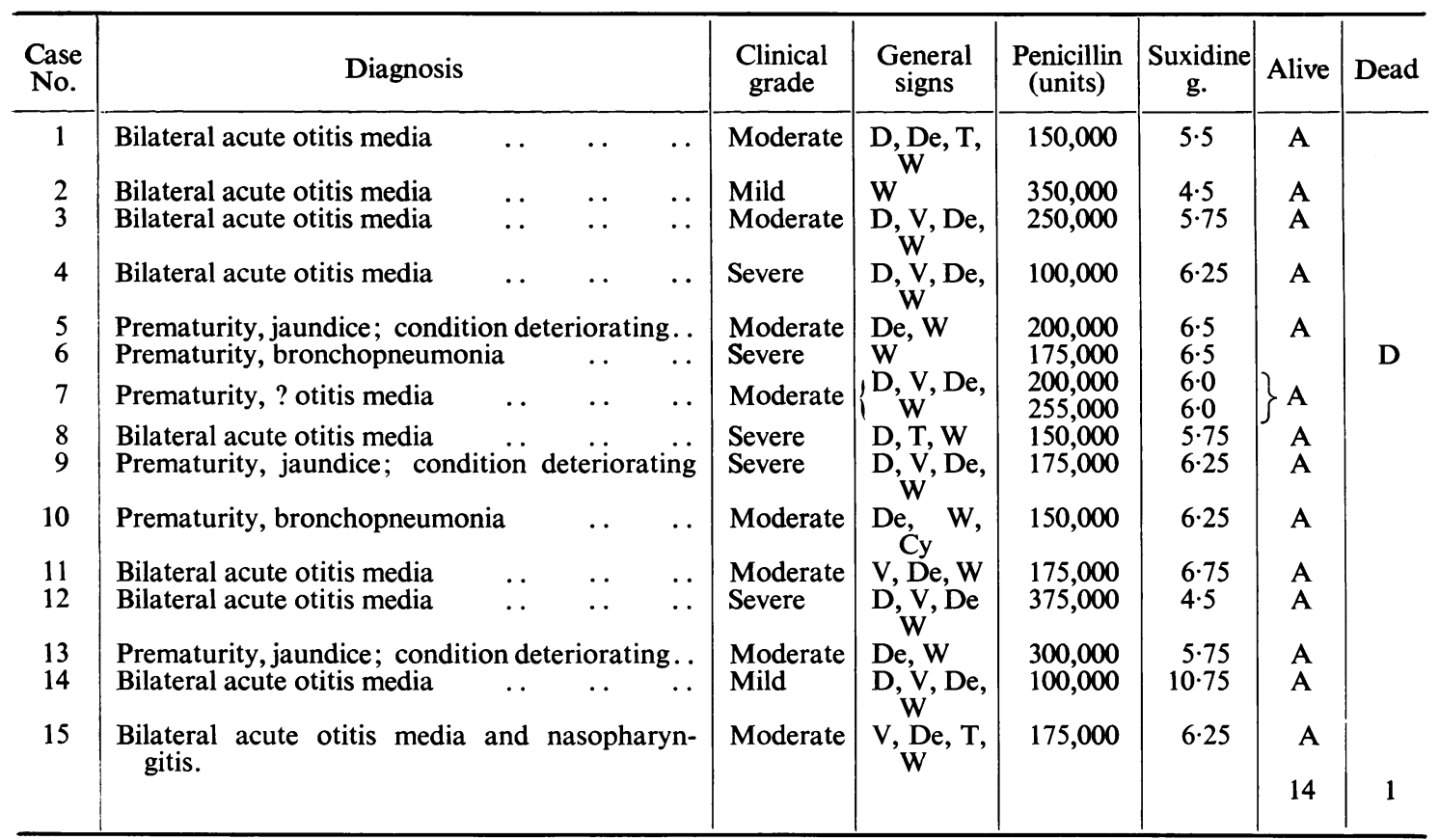

penicillin and sensitive to sulphonamide. Direct smear from the right middle ear showed some Gram positive cocci.

\section{Group C: Penicillin and Sulphasuxidine}

Five cases in this group were judged to be severely ill, eight moderately ill and two mildly ill. Six were premature infants of whom one died.

Symptoms. General symptoms occurred as follows: diarrhoea 8 , vomiting 8 , dehydration 12 , pyrexia 3 and loss of weight 15 . Temperature again only lasted one day after institution of treatment and varied from $99 \cdot 8^{\circ} \mathrm{F}$. to $101^{\circ} \mathrm{F}$. Loss of weight varied from 4 to $21 \mathrm{oz}$.

COURSE OF THE ILLNESS. There were nine cases of otitis media in whom the inflammation of the tympanic membranes settled in from three to eighteen days. In three an unusual phenomenon was observed. The inflammation seemed to come and go. One day the drums looked nearly normal and the next day as acutely inflamed as ever. These cases ultimately settled down completely. One was sufficiently dehydrated to require intravenous fluids; in two others the general response was rather slow, and in another, which also had nasopharyngitis, the ears settled clinically in six days but the nasopharyngitis continued for a longer period. Two of the premature infants required subcutaneous salines but, except for one who required two courses of treatment and in whom feeding difficulty was encountered, their progress was uneventful. Those who recovered regained weight lost as a result of the illness in periods varying from three to sixteen days.

BACTERIOLOGY IN LIFE. In thirteen cases bac- teriological examination of the faeces showed no evidence of pathogenic organisms, one being examined on two occasions. In one case faecal streptococci were grown and in another a specimen was not obtained.

Post-MORTem Findings. Post-mortem examination in the case who died revealed the presence of bronchopneumonia confirmed by microscopic section.

Post-mortem Bacteriology. Direct smear from the lungs showed coliform organisms and culture grew coliform organisms, resistant to penicillin but sensitive to sulphonamide and non-haemolytic streptococci, sensitive to penicillin but resistant to sulphonamide.

\section{Part II}

From the results described in Part I it would appear that the best results are obtained from the combination of penicillin and sulphasuxidine. The experiment was continued on these lines and two further groups remain to be described.

(A) A group treated with penicillin and sulphasuxidine to confirm the good results already obtained.

(B) A group treated with sulphasuxidine alone to test the efficacy of this drug in such infections.

\section{Group A}

Of this group nine were severely ill, ten moderately ill and one mildly ill. There were ten premature infants, of whom five died.

Sympтомs. General symptoms were as follows: diarrhoea 5 , vomiting 3 , dehydration 9 , pyrexia 5 
16. P.O.

16. P.O.
10.

9 .

8 .

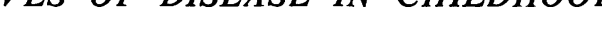

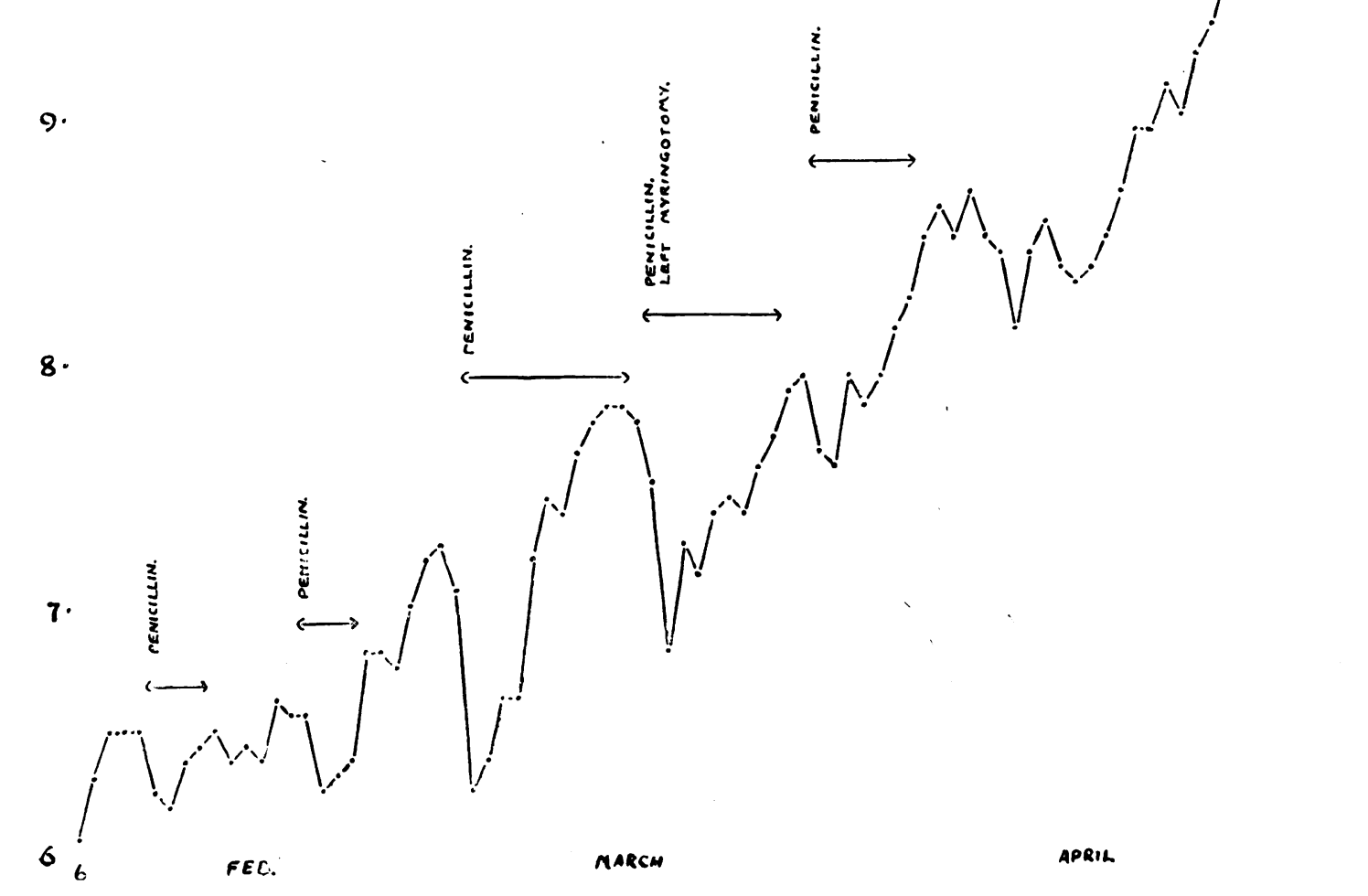

FIG. 1.

and loss of weight 16. Five premature infants had cyanotic attacks. In one case weight was stationary and three were too ill to be weighed. Temperature, which varied from $99^{\circ} \mathrm{F}$. to $105 \cdot 3^{\circ} \mathrm{F}$., settled in three cases in one to two days after treatment was begun. In the remaining two, temperature took twelve and twenty-seven days respectively to settle. Weight loss varied from 4 to $20 \mathrm{oz}$.

CoURSE OF THE ILlNess. Nine cases were diagnosed in life as suffering from otitis media. In these the inflammation of the tympanic membranes settled clinically in from five to twenty-three days. In three the ' coming and going' type of inflammation was noted. In two cases one ear only was affected to begin with, but the treatment did not prevent the other ear from becoming affected subsequently, as in case No. 9, in whom the otorrhoea ceased in six days but the other ear became acutely inflamed later, and took eleven days to settle clinically. The five deaths were premature infants, in all of whom bronchopneumonia was diagnosed. The remaining five premature infants consisted of two cases of bronchopneumonia, one of bronchitis and two were going steadily downhill. The progress of these cases was very satisfactory. In case No. 6 ont buttock became rather indurated, but subsided when injections were stopped. Case No. 13 did not progress well and required intravenous fluid. Those who recovered regained weight lost as a result of the illness in periods varying from six to forty-five days.

BACTERIOLOGY IN Life. In fifteen cases bacteriological examination of the faeces showed no evidence of pathogenic organisms. One specimen grew B. Morgan I and in four cases specimens were not obtained. A swab of the aural discharge in case No. 9 was taken and direct smear showed Gram positive cocci and coliform organisms. Culture grew Staphylococcus aureus, sensitive to penicillin and sulphonamide, and coliform organisms, resistant to penicillin and sensitive to sulphonamide. Fig. 2 is a photograph of the culture plate in this case. The upper test is the penicillin sensitivity test, where the colonies of resistant coliform organisms can be seen. In case No. 17, which had an abscess of the thigh, direct smear of the pus showed Gram positive cocci, while the culture plate was overgrown with coliform organisms. 
TABle 4

GROUP A: PENICILLIN AND SULPHASUXIDINE

\begin{tabular}{|c|c|c|c|c|c|c|c|}
\hline $\begin{array}{l}\text { Case } \\
\text { No. }\end{array}$ & Diagnosis & $\begin{array}{l}\text { Clinical } \\
\text { grade }\end{array}$ & $\begin{array}{l}\text { General } \\
\text { signs }\end{array}$ & $\begin{array}{l}\text { Penicillin } \\
\text { (units) }\end{array}$ & $\begin{array}{l}\text { Suxidine } \\
\text { g. }\end{array}$ & Alive & Dead \\
\hline 1 & $\begin{array}{l}\text { Bilateral otitis media, jaundice, congenital heart } \\
\text { disease. }\end{array}$ & Moderate & $\mathrm{D}, \mathrm{V}$ & 475,000 & 6.5 & A & \\
\hline 2 & Prematurity, jaundice; condition deteriorating. . & Moderate & D De, W. & 200,000 & 6.5 & A & \\
\hline 3 & Prematurity, jaundice; condition deteriorating. . & Moderate & $\mathbf{T}$, & 200,000 & & A & \\
\hline 4 & Bilateral otitis media & & & 275,000 & $6 \cdot 0$ & A & \\
\hline 5 & Prematurity, bronchitis and nasopharyngitis & Moderate & De, T, W & 325,000 & $6 \cdot 25$ & A & \\
\hline 6 & Bilateral otitis media and nasopharyngitis & Moderate & $\mathrm{T}, \mathrm{W}$ & 300,000 & $5 \cdot 0$ & A & \\
\hline 7 & Bilateral otitis media $\quad$. & Moderate & D, De, W & 375,000 & $6 \cdot 5$ & A & \\
\hline 8 & Bilateral otitis media $\ldots$ & Moderate & D, De, W & 400,000 & $6 \cdot 5$ & A & \\
\hline 9 & $\begin{array}{l}\text { Right otitis media and otorrhoea; left otitis } \\
\text { media. }\end{array}$ & Moderate & & $\left\{\begin{array}{l}175,000 \\
275,000\end{array}\right.$ & $\begin{array}{r}6 \cdot 5 \\
6 \cdot 5\end{array}$ & A & \\
\hline 10 & $\begin{array}{l}\text { Prematurity, bronchopneumonia, right otitis } \\
\text { media and subdural haemorrhage. }\end{array}$ & Severe & $\mathrm{Cy}$ & 75,000 & $6 \cdot 5$ & & D \\
\hline $\begin{array}{l}11 \\
12\end{array}$ & $\begin{array}{ll}\text { Prematurity, jaundice, bronchopneumonia } & \ldots \\
\text { Prematurity, bronchitis, bilateral otitis media } & \text {.. }\end{array}$ & $\begin{array}{l}\text { Severe } \\
\text { Severe }\end{array}$ & $\begin{array}{l}\text { De, W } \\
\text { W }\end{array}$ & $\begin{array}{r}75,000 \\
6,250\end{array}$ & $\begin{array}{l}6 \cdot 5 \\
0 \cdot 75\end{array}$ & & $\begin{array}{l}\text { D } \\
\text { D }\end{array}$ \\
\hline 13 & $\begin{array}{llll}\text { Bilateral otitis media } \quad \ldots & \ldots\end{array}$ & Severe & D, V, De, & $\left\{\begin{array}{l}175,000 \\
150,000 \\
200,000\end{array}\right.$ & $\overline{6 \cdot 5}$ & A & \\
\hline 14 & Bronchitis & Moderate & De, W & 200,000 & $6 \cdot 5$ & 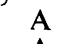 & \\
\hline 16 & 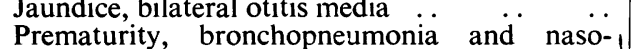 & Mo & & $\begin{array}{r}650,000 \\
150,000\end{array}$ & $\begin{array}{l}6 \cdot 5 \\
6 \cdot 5\end{array}$ & A & \\
\hline & pharyngitis. & Severe & $\mathrm{N}, \mathrm{W}, \mathrm{Cy}$ & $\left\{\begin{array}{l}13,000 \\
75,000\end{array}\right.$ & $\begin{array}{l}0.5 \\
4.5\end{array}$ & A & \\
\hline $\begin{array}{l}17 \\
18\end{array}$ & Right otitis media and abscess of thigh . & $\begin{array}{l}\text { Severe } \\
\text { Severe }\end{array}$ & V, De, W & 175,000 & $\begin{array}{l}6 \cdot 25 \\
6 \cdot 5\end{array}$ & A & $D$ \\
\hline 19 & Prematurity, bronchopneumonia & Severe & $\mathrm{N}, \mathrm{w}, \mathrm{Cy}$ & $\begin{array}{r}100,000 \\
9,375\end{array}$ & $1 \cdot 0$ & & D \\
\hline \multirow[t]{2}{*}{20} & Prematurity, bronchopneumonia & Severe & $\mathrm{Cy}$ & $\left\{\begin{array}{l}200,000 \\
250,000\end{array}\right.$ & $\begin{array}{l}6 \cdot 5 \\
6 \cdot 5\end{array}$ & A & \\
\hline & & & & & & 15 & 5 \\
\hline
\end{tabular}

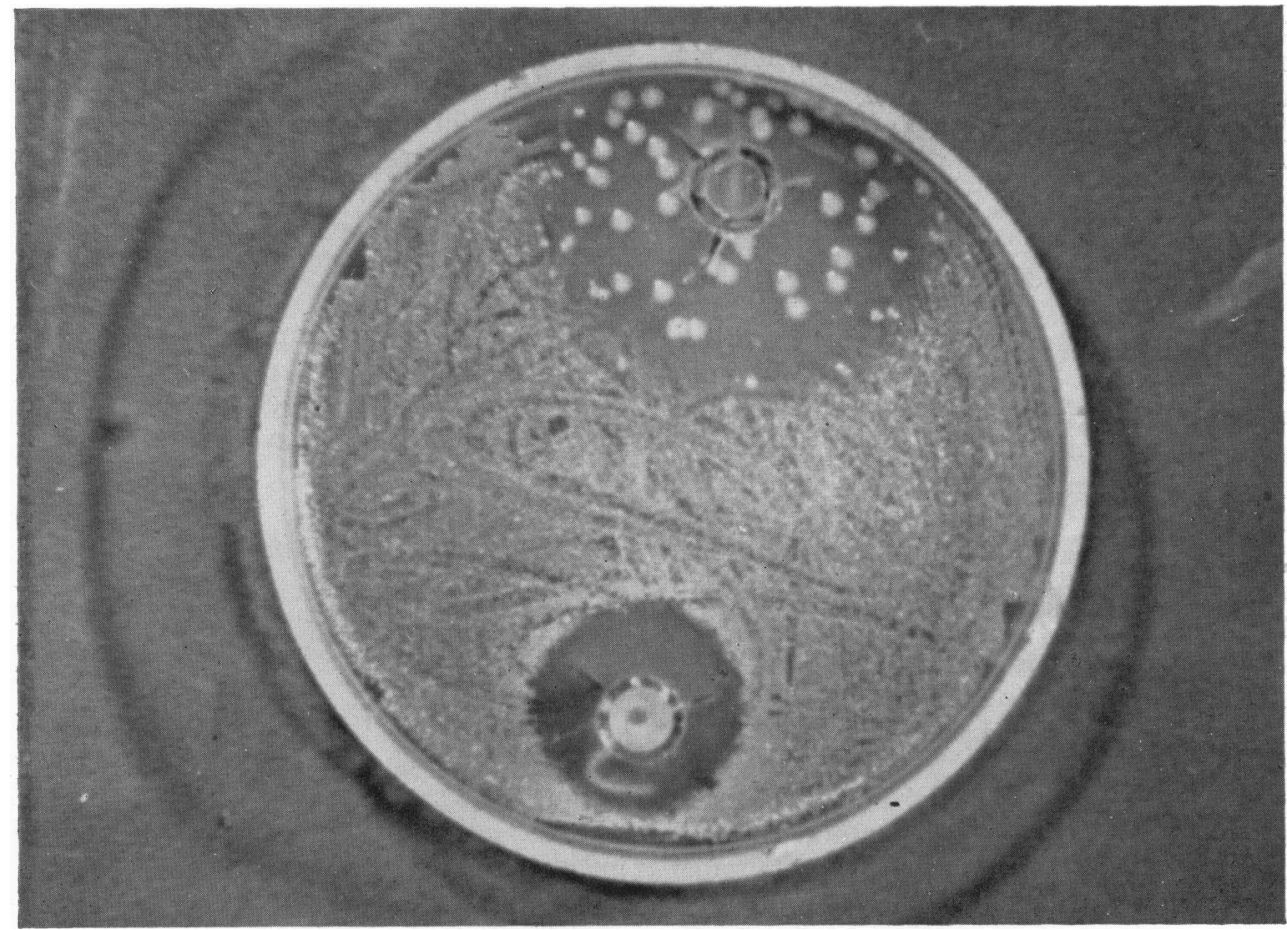

FIG. 2.-Culture plate (case No. 9) showing penicillin sensitivity test (above) with colonies of resistant coliform organisms. 
TABLE 5

GROUP B: SULPHASUXIDINE ALONE

\begin{tabular}{|c|c|c|c|c|c|c|c|}
\hline $\begin{array}{l}\text { Case } \\
\text { No. }\end{array}$ & Diagnosis & $\begin{array}{l}\text { Clinical } \\
\text { grade }\end{array}$ & $\begin{array}{l}\text { General } \\
\text { signs }\end{array}$ & $\begin{array}{l}\text { Penicillin } \\
\text { (units) }\end{array}$ & $\begin{array}{l}\text { Suxidine } \\
\text { g. }\end{array}$ & Alive & Dead \\
\hline $\begin{array}{l}1 \\
2\end{array}$ & 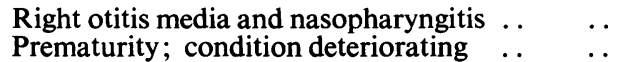 & $\begin{array}{l}\text { Mild } \\
\text { Moderate }\end{array}$ & $\begin{array}{l}\text { D, V, W } \\
\text { De, T, W }\end{array}$ & 二 & $\begin{array}{l}9 \cdot 25 \\
6 \cdot 25\end{array}$ & $\begin{array}{l}\text { A } \\
\text { A }\end{array}$ & \\
\hline 3 & $\begin{array}{l}\text { Bilateral otitis media, nasopharyngitis, abscess of } \\
\text { thigh and cellulitis of elbow. }\end{array}$ & Severe & $\mathrm{D}, \mathrm{V}, \mathrm{W}$ & 50,000 & $12 \cdot 25$ & A & \\
\hline 4 & Right otitis media and nasopharyngitis .. $\quad$.. & Moderate & W & 225,000 & $15 \cdot 25$ & A & \\
\hline 5 & Bilateral otitis media and nasopharyngitis & Moderate & D, De, W & 350,000 & $12 \cdot 25$ & A & \\
\hline $\begin{array}{l}6 \\
7\end{array}$ & $\begin{array}{l}\text { Bilateral otitis media and nasopharyngitis } \\
\text { Prematurity: condition deteriorating }\end{array}$ & $\begin{array}{l}\text { Moderate } \\
\text { Severe }\end{array}$ & $\begin{array}{l}\text { W } \\
\text { D. De, W }\end{array}$ & $17 \underline{17000}$ & $\begin{array}{c}12 \cdot 25 \\
8 \cdot 5\end{array}$ & $\begin{array}{l}\text { A } \\
\text { A }\end{array}$ & \\
\hline 8 & Bilateral otitis media and bronchopneumonia $\ldots$ & Severe & D, De, T, & 212,500 & $9 \cdot 25$ & & D \\
\hline 9 & Bilateral otitis media and bronchopneumonia .. & Severe & D, De, T, & 250,000 & $18 \cdot 25$ & & D \\
\hline 10 & $\begin{array}{l}\text { Prematurity, bronchopneumonia and subdural } \\
\text { haemorrhage. }\end{array}$ & Severe & $\mathrm{D}, \mathrm{De}, \mathrm{W}$ & - & $6 \cdot 25$ & & $\mathbf{D}$ \\
\hline 11 & Bronchopneumonia, jaundice $\quad .$. & Severe & D, V, De, & 100,000 & $9 \cdot 25$ & & $\mathbf{D}$ \\
\hline 12 & Prematurity, jaundice; condition deteriorating & Severe & De, W & $\begin{array}{r}25,000 \\
150000\end{array}$ & $\begin{array}{r}6 \cdot 25 \\
12 \cdot 25\end{array}$ & & D \\
\hline 13 & $\begin{array}{llll}\text { Bilateral otitis media } & . & \ldots & \end{array}$ & Severe & $\left\{\begin{array}{l}\mathrm{D}, \mathrm{V}, \mathrm{De}, \\
\mathrm{T}, \mathrm{W}\end{array}\right.$ & $\begin{array}{l}150,000 \\
100,000 \\
200,000\end{array}$ & $\underline{-12 \cdot 23}$ & A & \\
\hline 14 & Bilateral otitis media & Moderate & $\left\{\begin{array}{l}\mathrm{D}, \mathrm{V}, \mathbf{\mathrm { De }}, \\
\mathrm{T}, \mathrm{W}\end{array}\right.$ & $\begin{array}{l}225,000 \\
175,000\end{array}$ & $\begin{array}{r}12 \cdot 25 \\
6 \cdot 25\end{array}$ & A & \\
\hline $\begin{array}{l}15 \\
16\end{array}$ & $\begin{array}{l}\text { Prematurity, jaundice; } \\
\text { Bilateral otitis media } \begin{array}{ccc}\text { condition deteriorating } \\
.\end{array} \quad . .\end{array}$ & $\begin{array}{l}\text { Moderate } \\
\text { Severe }\end{array}$ & $\begin{array}{l}\text { De, W } \\
\text { D, V, De, } \\
\text { W }\end{array}$ & $27 \overline{5,000}$ & $\begin{array}{l}6 \cdot 25 \\
9 \cdot 25\end{array}$ & $\begin{array}{l}\text { A } \\
\text { A }\end{array}$ & \\
\hline $\begin{array}{l}17 \\
18\end{array}$ & $\begin{array}{l}\text { Bilateral otitis media and nasopharyngitis } \\
\text { Bilateral otitis media and nasopharyngitis }\end{array}$ & $\begin{array}{l}\text { Mild } \\
\text { Moderate }\end{array}$ & $\begin{array}{l}\text { V,W } \\
\text { D, V,w }\end{array}$ & 200,000 & $\begin{array}{l}9 \cdot 25 \\
9 \cdot 75\end{array}$ & $\begin{array}{l}\text { A } \\
A\end{array}$ & \\
\hline 19 & Left otitis media and nasopharyngitis .. & Moderate & D, V, De, & & $9 \cdot 75$ & A & \\
\hline 20 & Prematurity, jaundice; condition deteriorating & Moderate & $\mathrm{De}, \mathrm{W}$ & - & $6 \cdot 25$ & $\begin{array}{l}\text { A } \\
15\end{array}$ & 5 \\
\hline
\end{tabular}

Post-MORTEM Findings. The results of the postmortem examinations were as follows. In four of the fatal cases the presence of bronchopneumonia was verified and in two confirmed by microscopic section. One of these was also found to have a small subdural haemorrhage and right acute otitis media. In the case of the fifth infant who died, bronchopneumonia was suspected in life but only bronchitis was found together with bilateral otitis media.

Post-mortem Bacteriology. Swabs from the right middle ear and lungs in case No. 10 grew coliform organisms, resistant to penicillin but sensitive to sulphonamide. In case No. 11 culture from the lung grew coliform organisms, resistant to penicillin but sensitive to sulphonamide. Swabs from the middle ear in case No. 12 grew coliform organisms, resistant to penicillin but sensitive to sulphonamide.

In this group it was intended to test the efficacy of sulphasuxidine. Only about 5 per cent. of this drug is absorbed (M.R.C., War Memo., No. 10) and it is active against organisms of the coliform group, causing a fall in the numbers of these organisms in the intestinal tract. Used alone it is not therefore likely to be of benefit in the type of infection under treatment, and in practice it was often found necessary to proceed to penicillin administration. In the above table where no penicillin is mentioned none was given. As sulphasuxidine was not given con- currently with the penicillin the following doses were employed: $0.75 \mathrm{~g}$. as the initial dose, and then $0.5 \mathrm{~g}$. four-hourly, to mature infants, and $0.5 \mathrm{~g}$. as the initial dose and then $0.25 \mathrm{~g}$. three-hourly to premature infants. Sulphasuxidine by itself was given a fair trial, the courses lasting three to six days and only if improvement was not manifest was penicillin given. Penicillin was on one occasion given in doses of 12,500 units daily (second course in case No. 14).

In this group nine were considered to be severely ill, nine moderately ill and two mildly ill. There were six premature infants, of whom two died.

Symptoms. General symptoms were displayed as follows: diarrhoea 13 , vomiting 9 , dehydration 14, pyrexia 7 and loss of weight 20 . Temperature lasted at most three days after treatment was begun, usually only one day, and varied from $99 \cdot 2^{\circ} \mathrm{F}$. to $104 \cdot 8^{\circ} \mathrm{F}$. In one case (No. 9) it rose again and remained uncontrolled. Loss of weight varied from 4 to $22 \mathrm{oz}$.

COURSE OF THE ILlness. Thirteen cases suffered from otitis media and in ten of these the administration of penicillin became necessary because sulphasuxidine had no apparent effect on the inflammation of the tympanic membranes. In two cases (No. 13 and 14) relapse took place even after penicillin, and in those who recovered the ears settled clinically in four to fourteen days after penicillin was given. Two of the thirteen cases 
died (No. 8 and 9), and one of these developed bronchopneumonia the day after penicillin was begun; in the other the temperature settled, rose again, and remained uncontrolled. Penicillin had no effect on this case. In case No. 3 the infant was taken from hospital against advice when only a small quantity of penicillin had been given. This child also developed cellulitis of the elbow and an abscess of the thigh, and penicillin had had no effect at the time of discharge from hospital. Possibly in cases No. 3,8 and 9 penicillin was given too late. The remaining three cases of otitis media (cases No. 1, 17 and 19) settled well with sulphasuxidine alone in four to five days, but in two an accompanying nasopharyngitis continued for a longer period. Two were only mildly ill and one moderately ill. The remaining seven cases of the group consist of six premature infants who were going downhill and one case of pneumonia, who had both sulphasuxidine and penicillin but unfortunately died. Of the six premature infants (No. $2,7,10,12,15$ and 20) one had penicillin treatment for one day following unsuccessful sulphasuxidine therapy but died. One of those treated with sulphasuxidine alone died. Three responded very well to sulphasuxidine alone and another progressed well at first and latterly was pyrexial for no apparent reason but ultimately recovered.

The following cases in this group (No. 8, 9, 13, 14 and 16) are described in greater detail. In all but No. 8 , only that part of the weight curve dealing with the illness is shown.

BACTERIOLOGY IN Life. In nineteen instances bacteriological examination of the faeces showed no evidence of pathogenic organisms. In one case a specimen was not obtained. Urine examination in two cases was also negative. Pus from the abscess of thigh in case No. 3 grew Staphylococcus aureus.

POST-MORTEM Findings. In cases No. 8, 9, 10 and 12, the presence of bronchopneumonia was confirmed by microscopic sections. In case No. 8 right acute otitis media and mastoiditis were also found. The middle ears in case No. 9 were found to be normal, probably due to treatment, and the liver looked fatty but was normal on section. In case No. 10 bilateral acute otitis media, subperiosteal haematoma and subdural haemorrhage into the posterior fossa were also found and in case No. 12 right acute otitis media. Permission for postmortem examination was refused in case No. 11 .

POST-MORTEM BACTERIOlogy. Splenic culture in case No. 9 grew B. Coli. Direct smears from the middle ears in case No. 10 showed coliform organisms and Gram positive cocci while cultures from the ears and lungs grew coliform organisms, resistant to penicillin but sensitive to sulphonamide. Cultures from the lungs in case No. 12 grew coliform organisms, resistant to penicillin, and non-haemolytic streptococci, resistant to sulphonamide.

\section{Discussion}

The group treated with penicillin alone (Part I, Group A) is very disappointing and the good results reported earlier have not been maintained. This group contains a high proportion of premature infants, among whom the death rate was 72.7 per cent. Comparing this high figure with that for premature infants suffering from similar infections and treated with penicillin and sulphonamide, the death rate is 42.8 per cent., a considerable improvement. The virulence of such infections seems to reach its maximum in the early months of the year, when the present experiment was conducted, and this probably accounts for the difference in the results of the previously reported series treated with penicillin alone and the present group of cases treated with penicillin alone. The better results obtained by combining sulphonamide with penicillin constitute a strong argument for this mode of treatment. Burns and Gunn (1944) describe four cases of gastroenteritis, associated with otitis media and mastoiditis, two of whom received penicillin locally into mastoidectomy wounds, one intravenously and one, which developed pneumococcal meningitis, both intramuscularly and intrathecally. One of these cases who recovered also had sulphathiazole and three, one of whom died, had sulphamezathine. The combination therefore seems to give better results than penicillin alone.

The next problem is to decide which of the many sulphonamide drugs is the most efficacious. If the composition and severity of the groups described in the present series are disregarded, it appears that, of the two sulphonamides used, combination with sulphasuxidine gives the better results. The rationale of using sulphasuxidine in this way lies in the fact that it reduces the numbers of the intestinal coliform organisms (M.R.C. War Memo. No. 10). Coliform infections are peculiarly common in the neonatal period of life. Macgregor (1939), in her exhaustive account of neonatal pneumonias, found organisms of the colon bacillus group and Staphylococcus aureus the commonest pathogenic organisms. Both in the previously reported series and in the present series coliform organisms have been grown frequently, and possibly invasion by these organisms as the illness continues is a common happening. For example, in case No. 3 (Part I, Group A) the first nasal swab grew Staphylococcus aureus, sensitive to penicillin and sulphonamides, while the second, thirteen days later, grew coliform organisms, resistant to penicillin but sensitive to sulphonamide. On the other hand coliform organisms may militate against success in another way. Abraham and Chain (1944) found that B. Coli produces penicillinase which inactivates penicillin completely. Whatever may be the rôle of coliform organisms, any treatment calculated to reduce their number seems reasonable. Sulphasuxidine alone was on the whole unsatisfactory, although it is noteworthy that four out of five premature infants treated with sulphasuxidine alone recovered.

It can be seen from table 6 that the most dangerous and difficult case to treat is the premature infant with bronchopneumonia. The results in acute otitis media are very satisfactory indeed. 


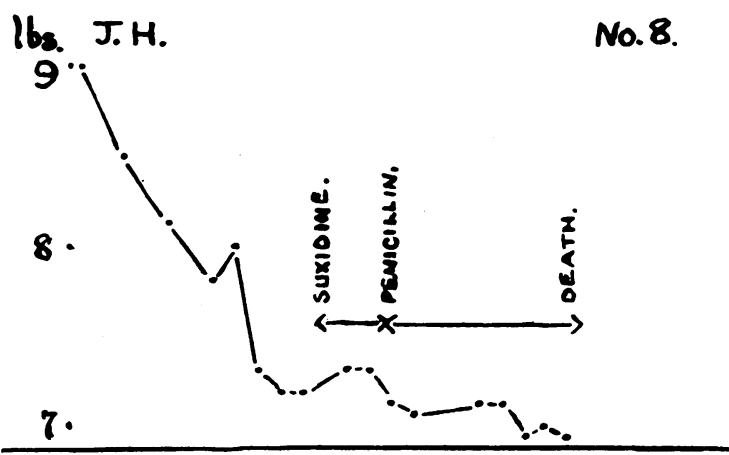

8. J. H., male, born 24-2-45, developed acute otitis media, with considerable loss of weight and cyanotic attacks. Suxidine had no effect on otitis media, and penicillin was begun, but little change in the ears was seen. Cyanotic attacks, probably due to bronchopneumonia, began before the otitis developed, but had ceased for some days. They began again during penicillin treatment.

No9.

9. B. M., male, born 9-1-45, developed acute otitis media with some weight loss. The inflammation of the tympanic membranes did not settle

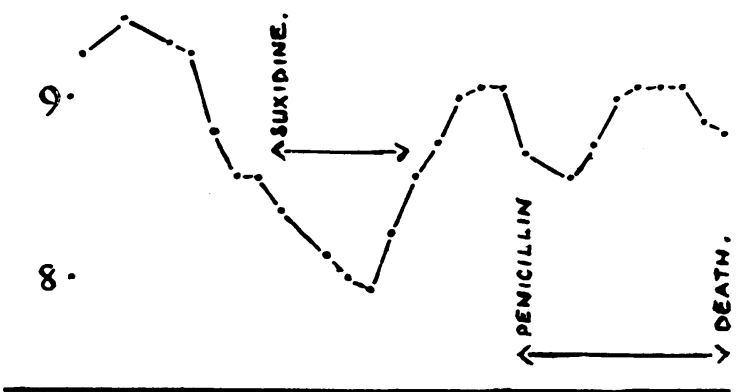
although suxidine was given for six days. Weight was regained but lost again with pyrexia and acutely inflamed drums. Penicillin caused some improvement, but the drums never became quite normal. Bronchopneumonia had developed meanwhile.

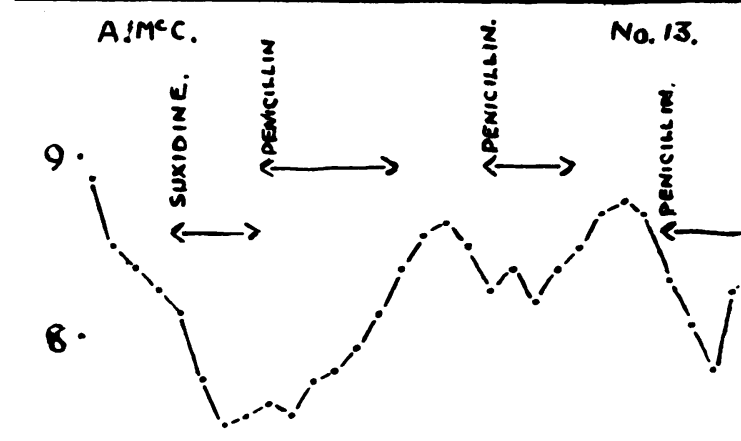

13. A. McC., female, born 30-3-45, developed otitis media and suxidine had no effect. Penicillin was given and improvement and gain in weight began. The ears settled clinically in six days. Unfortunately relapse occurred and further courses of penicillin were necessary. The infant did well after the third course of penicillin and was $10 \mathrm{lb}$. in weight when discharged from hospital.

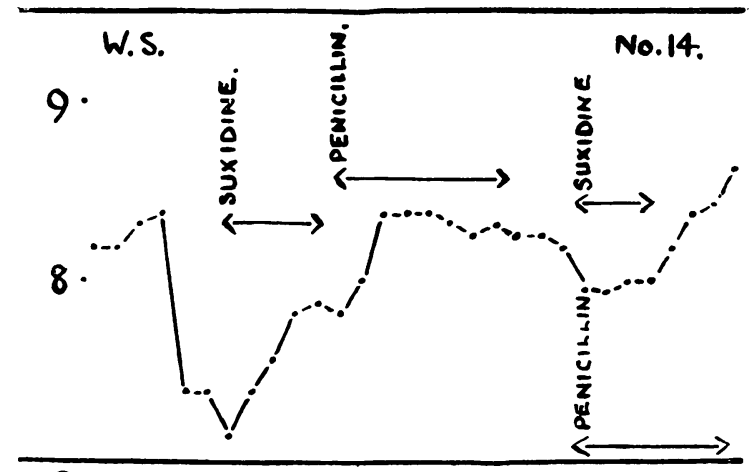

8. C.M.

No. 16.

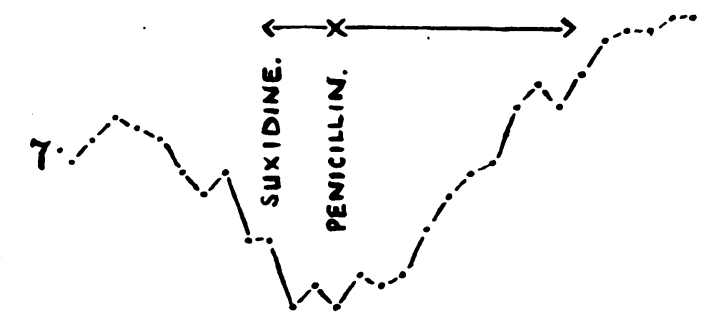

14. W. S., male, born 16-5-45, developed otitis media and some improvement occurred with suxidine, but the tympanic membranes did not become normal. When gain ceased, penicillin was begun and ears settled clinically in eight days. Relapse occurred and a combined course was given, when ears settled clinically in seven days and gain in weight was satisfactory. The fact that the curve remains flat after the first course suggests that the inflammation had not completely settled.

16. C. M., male, born 23-4-45, developed acute otitis media and suxidine had no effect. Penicillin was given with immediate improvement and gain in weight. The ears settled clinically in eleven days. 
Only one myringotomy was necessary and no mastoid operations. This is a great improvement on treatment with sulphonamides alone, when the death rate was $14 \cdot 1$ per cent. and myringotomies and operations were frequent (Henderson and Couper, 1946).

\section{TABLE 6}

COMBINED ANALYSIS OF THE PENICILLIN AND SULPHASUXIDINE TREATED GROUPS

\begin{tabular}{|c|c|c|}
\hline & Number & Deaths \\
\hline Total & 47 & $\begin{array}{l}10(21 \cdot 2 \\
\text { per cent })\end{array}$ \\
\hline $\begin{array}{lll}\text { Premature infants } & \ldots & \ldots\end{array}$ & 17 & $\begin{array}{l}7(41 \cdot 1 \\
\text { per cent. })\end{array}$ \\
\hline Mature infants & 30 & $\begin{array}{l}3 \text { (10 per } \\
\text { cent.) }\end{array}$ \\
\hline $\begin{array}{l}\text { Prematurity; condition deteri- } \\
\text { orating. }\end{array}$ & 7 & 1 \\
\hline $\begin{array}{l}\text { Prematurity and bronchopneu- } \\
\text { monia. }\end{array}$ & 7 & $\begin{array}{l}5(71 \cdot 4 \text { per } \\
\text { cent.) }\end{array}$ \\
\hline $\begin{array}{l}\text { Prematurity, bronchitis and } \\
\text { nasopharyngitis. }\end{array}$ & 2 & \\
\hline $\begin{array}{l}\text { Prematurity, bronchitis and } \\
\text { otitis media. }\end{array}$ & 1 & 1 \\
\hline $\begin{array}{l}\text { Bilateral acute otitis media and } \\
\text { nasopharyngitis. }\end{array}$ & 26 & \\
\hline Bronchopneumonia $\quad \therefore \quad \therefore$ & 1 & 1 \\
\hline $\begin{array}{l}\text { Bronchopneumonia, otitis media } \\
\text { and mastoiditis. }\end{array}$ & 2 & 2 \\
\hline $\begin{array}{lll}\text { Bronchitis } & \ldots & \ldots\end{array}$ & 1 & \\
\hline
\end{tabular}

\section{Conclusions}

(1) The previously reported good results from treatment with penicillin alone during September, October and November have not been continued in the early months of the year, probably due to differences in the virulence of the infections.

(2) Better results are obtained by combining penicillin treatment with sulphonamide treatment.

(3) Two sulphonamides were tested, sulphathiazole and sulphasuxidine, and of the two, sulphasuxidine proved the better when combined with penicillin.

(4) Further investigation with other drugs of the sulphonamide group and with different doses of penicillin are necessary.

Thanks are due to Dr. H. H. Macwilliam, Medical Superintendent, Walton Hospital, Liverpool, for permission to publish this paper and to Prof. T. B. Davie, Professor of Pathology in the University of Liverpool and Distribution Officer of the Liverpool Medical School Penicillin Committee, for much helpful advice.

\section{REFERENCES}

Abraham, E. P., and Chain, E. (1944). Brit. med. Bull., 2, 16.

Burns, M. B., and Gunn, W. (1944). Brit. med. J., $2,178$. Couper, E. C. R. (1945). Arch. Dis. Childh., 20, 117.

Henderson, M., and Couper, E. C. R. (1946). Arch. Dis. Childh., 21, 23.

MacGregor, A. R. (1939). Arch. Dis. Childh., 14, 323.

Medical Research Council (1943). War Memorandum, No. 10. 